\title{
Prevalence of anti-Leptospira spp. antibodies in cows in the municipalities of Nova Guarita and Nova Santa Helena, Mato Grosso State, Brazil
}

\author{
[Prevalência de anticorpos anti-Leptospira spp. em vacas nos municípios de Nova Guarita e Nova \\ Santa Helena, Mato Grosso, Brasil]
}

\section{"Artigo Científico/Scientific Article"}

\author{
Rafael dos Santos ${ }^{1}$, Janderson Ananias de Oliveira $^{1}$, Francielly Lopes ${ }^{1}$, Bruno Gomes de Castro ${ }^{1}$, \\ Rogério Oliveira Rodrigues ${ }^{2}$, Rafael Romero Nicolino ${ }^{3}$, Luciano Bastos Lopes $^{4 *}$ \\ ${ }^{1}$ Federal University of Mato Grosso, Sinop-MT, Brazil. \\ ${ }^{2}$ Secretary of Agriculture/SC, Eldorado do Sul-RS, Brazil. \\ ${ }^{3}$ Agronomic \& Animal Sciences Institute Federal, University of Jequitinhonha and Mucuri Valleys - UFVJM, Cachoeira, \\ Unaí - MG, Brazil. \\ ${ }^{4}$ Embrapa Agrosilvopastoral, Sinop-MT, Brazil. \\ *Autor para correspondência/Corresponding author: E-mail: luciano.lopes@embrapa.br
}

\begin{abstract}
Frequently, leptospirosis is related to reproductive problems in livestock, such as abortion, increased embryonic mortality and stillbirths. Unfortunately, there are few reports addressing the prevalence of the disease in cattle in the North of Mato Grosso State (MT), Brazil. The aim of the present study was to determine the presence of anti-Leptospira spp. antibodies in cattle in the municipalities of Nova Guarita and Nova Santa Helena, MT. Nine hundred and eighty blood samples were taken from cows aged $\geq 24$ months from 49 farms slaughtered in Sinop, MT. Microscopic Agglutination Test was used for the detection of anti-Leptospira spp. antibodies. The animal prevalence was $17.9 \%(95 \% \mathrm{CI}=15.6-20.5 \%)$. The prevalence observed in the municipalities Nova Guarita and Nova Santa Helena was $13.4 \%(95 \% \mathrm{CI}=12.8-14.1 \%)$ and $23.2 \%(95 \%$ CI $=22.0-24.3 \%)$, respectively. The herd prevalence was $83.6 \%(95 \% \mathrm{CI}=79.4-87.8 \%)$. The most frequent serovar was Wolffi (47.7\%), followed by Hardjo (16.1\%), Hardjo - Bolivia sample (11.0\%), Australis (7.4\%), Grippotyphosa (4.6\%), Pomona (3.4\%), Batavie (3.4\%), Autumnalis (1.7\%), Icterohaemorrhagiae (1.7\%), Hebdomadis (1.1\%), Hardjo-bovis (1.1\%), and Castellonis (0.5\%). Infection by Leptospira spp. is endemic in both municipalities, reinforcing the need for new epidemiological studies to subsidize the control of the disease in Mato Grosso.
\end{abstract}

Keywords: cattle; epidemiology; leptospirosis; Microscopic Agglutination Test; slaughterhouse.

\section{Resumo}

A leptospirose está frequentemente relacionada a problemas reprodutivos em rebanhos bovinos, como abortamentos, aumento da mortalidade embrionária e nascimento de bezerros fracos. Infelizmente, existem poucos estudos envolvendo a prevalência da enfermidade em bovinos na região norte do Estado de Mato Grosso, Brasil. O presente estudo teve como objetivo determinar a presença de anticorpos anti-Leptospira spp. em rebanhos bovinos dos municípios de Nova Guarita e Nova Santa Helena, Mato Grosso. No total, 980 amostras de sangue foram coletadas de fêmeas bovinas oriundas de 49 propriedades, todas com idade $\geq 24$ a meses abatidas em abatedouro frigorifico localizado no município de Sinop, MT. O teste de Soroaglutinação Microscópica foi utilizado para a detecção de anticorpos anti-Leptospira spp. A prevalência animal foi de 17,9 $\%(95 \%$ IC $=15,6-20,5 \%)$. A prevalência observada entre os municípios de Nova Guarita e Nova Santa Helena foi de $13,4 \%(95 \%$ IC $=12,8-14,1 \%)$ e $23,2 \%(95 \%$ IC $=22,0-24,3 \%)$, respectivamente. A prevalência de propriedades foco foi de $83,6 \%$ (95\% IC $=79,4-87,8 \%)$. A sorovariedade mais frequente foi a Wolffi $(47,7 \%)$, seguido pelas sorovariedades Hardjo (16,1\%); Hardjo amostra Bolívia (11,0\%); Australis (7,4\%); Grippotyphosa (4,6\%); Pomona (3,4\%); Batavie (3,4\%); Autumnalis (1,7\%); Icterohaemorrhagiae $(1,7 \%)$; Hebdomadis $(1,1 \%)$; Hardjobovis $(1,1 \%)$ e Castellonis $(0,5 \%)$. Concluiu-se que a infecção por Leptospira spp. é endêmica nos dois os municípios, reiterando a necessidade de novos estudos epidemiológicos para subsidiar o controle da doença em Mato Grosso.

Palavras-chave: bovinos; epidemiologia; leptospirose; Soroaglutinação Microscópica; abatedouro.

Recebido 16 de outubro de 2017. Aceito 20 de novembro de 2018.

DOI: https://doi.org/10.26605/medvet-v12n4-2457 


\section{Introducion}

Among top ten beef exporting countries in world, Brazil, India, Australia and the U.S. together has projected for $2017,73 \%$ of total exports. Brazil stands out for having the second largest cattle herd in the planet, with approximately 212.3 million head. Mato Grosso must be highlighted, the state holds 32 million head, which represents $14 \%$ of the national herd according to the "Instituto de Defesa Agropecuária de Mato Grosso" (INDEA, 2016).

Despite the expressive numbers and the potential of expansion of the Brazilian livestock sector, various factors can affect the efficiency of production systems, such as nutrition and reproductive performance. Among these and other issues, animal health must be highlighted as well. Some microorganisms are potentially capable to trigger reproductive losses, including spirochete bacteria of the genus Leptospira spp. Leptospirosis causes significant economic losses to livestock, mainly due to reproductive disorders such as abortions, stillbirths, decreases in meat and milk production, reproductive failures; besides others costs related to veterinary assistance, medications, and immunization (Girio et al., 2005).

Some of its serovarieties are pathogenic to cattle, affecting also wild animals and, accidentally, humans (Ellis, 2015). The disease is widespread and most prevalent in tropical and subtropical countries, mainly during high rainfall periods (Sarmento et al., 2012). In Brazil, leptospirosis is considered as endemic, with prevalences ranging from 15 to $98.8 \%$ and serovar Hardjo, Wolffi, and Pomona being the most prevalent (Figueiredo et al., 2009; Sarmento et al., 2012; Kremer et al., 2015). However, other serovarieties have been isolated and identified in Brazilian herds, e.g., Guaicurus, Hardjo (Hardjoprajitno), Hardjo - Lagoa sample, Hardjo Bolivia sample, Icterohaemorrhagiae, Georgia, and Goiano (Sarmento et al., 2012; Miraglia, 2013; Nicolino et al., 2014; Kremer et al., 2015).

Based on the economic importance of the livestock sector to the economy of Mato Grosso State and the negative interference of bovine leptospirosis on reproduction, a serological survey was carried out to determine the prevalence of antiLeptospira spp. antibodies in cows aged $\geq 24$ months in the municipalities of Nova Guarita and Nova Santa Helena; Mato Grosso, Brazil.

\section{Material and Methods}

The authors whose names are listed above certify that they have not committed a willful act of abuse or cruelty or neglect animal rights included on this study. Besides, all the procedures recommended by OIE to apply the diagnosis test were used as described in methodology.

The study covered two municipalities located in the Northern Mato Grosso: Nova Guarita $\left(10^{\circ} 18^{\prime} 30^{\prime \prime} \mathrm{S} ; 55^{\circ} 24^{\prime} 17^{\prime \prime} \mathrm{W}\right)$ and Nova Santa Helena $\left(10^{\circ} 49^{\prime} 12^{\prime \prime} \mathrm{S} ; 53^{\circ} 21^{\prime} 3^{\prime \prime} \mathrm{W}\right)$. According to the Köppen classification, the climate in the region is characterized as an Aw type (tropical with rainy summers and dry winters) where $90 \%$ of the rainfall occurs between October and April (Souza et al., 2013).

Sampling was conducted in two stages: (i) in each municipality, cattle herds, which were the primary sampling units, were randomly selected; and (ii) in each selected herd, a sample was taken of cows aged 2 years or older, the secondary sampling units. The herd sample size was calculated according to Dean et al. (1994) using StatCalc module from EpiInfo 6.04d, assuming a simple random sample of herds and considering the following parameters: estimated herd prevalence $(\mathrm{p}=50 \%)$, desired precision $(15 \%)$, and confidence level (95\%), resulting in a sample of 40 herds and 383 animals. The random sampling of herds was performed using the registry of "Instituto de Defesa Agropecuária de Mato Grosso" | INDEA. According to the official files, these municipalities have 667 livestock farms; approximately 244,394 heads, and among them 106,299 cows aged $\geq 24$ months (INDEA, 2015). The prevalence of positive animals and properties was estimated according to the method described by Dohoo et al. (2003), using the Stata $11^{\circledR}$ statistical package (Statistics, Stata Corporation, USA).

Samples were obtained from one slaughterhouse located in Sinop/MT. Approximately $10 \mathrm{~mL}$ of blood were collected per cow between January 2015 to April 2016, totaling 980 samples from 49 farms. After sampling, tubes were sent to the Laboratory of Infectious Diseases at the "Universidade Federal de Mato Grosso" to be centrifuged at 3,000 rpm for $10 \mathrm{~min}$; then serum samples were aliquoted into $1.5-\mathrm{mL}$ micro tubes and preserved at $-20{ }^{\circ} \mathrm{C}$ until the serological analysis. 
The Microscopic Agglutination Test (MAT) was performed as described previously by Galton et al. (1965) and Cole, Sulzer and Pursell (1973) and modified by Herrmann et al. (2004) in the "Instituto Desidério Finamor", located in Eldorado do Sul/RS; Brazil. Twenty serovarieties were used, as follows: Australis, Autumnalis, Batavie, Hardjo - Bolivia sample, Castellonis, Calledoni, Grippotyphosa, Hardjo, Hardjo-bovis, Hebdomadis, Icterohaemorrhagiae, Javanica, Hardjo - Lagoa sample, Hardjo - Norma sample, Panama, Pomona, Serjroe, Shermani, Szwajizak, and Wolffi. The antigens were obtained from a bacterial bank replicated weekly in growth medium enriched with bovine serum albumin (BSA). The replication was performed in Ellinghausen McCullough growth medium, modified by Johnson and Harris (1967), and kept in a bacteriological incubator at $28^{\circ} \mathrm{C}$. Antigens were used after seven days of incubation. The concentration corresponded to number one on the scale of Mcfarland (100 to 200 Leptospira spp. per microscopic field), analyzing the absence of contaminations and auto-agglutinations. Next, the serum samples were diluted at 1:5 and then serial
1:2 ratio dilutions were performed. Subsequently, the diluted samples were incubated in a bacteriological incubator at $28{ }^{\circ} \mathrm{C}$ for one hour and then the material was read by dark-field microscopy (Herrmann et al., 2004).

Sera were screened at a dilution ratio of 1:100 and those that showed 50\% agglutination or more were titrated by serial 1:2 geometric dilutions, thereby preventing a diagnosis of false positive animals. The serum titer was the reciprocal of the highest dilution that showed a positive result. Farms diagnosed with at least one reactive animal for Leptospira ssp. were considered positive, considering the MAT method.

\section{Results}

The animal prevalence observed for antiLeptospira spp. antibodies was $17.9 \%(95 \% \mathrm{CI}=$ 15.6-20.5\%), based on the analysis of 967 samples. Considering the municipalities alone, a prevalence of $13.4 \%(95 \%$ CI $=12.8 \%-14.1 \%)$ reactive animals was found in Nova Guarita and $23.2 \%$ $(95 \%$ CI $=22.0-24.3 \%)$ in Nova Santa Helena (Table 1).

Table 1. Animal prevalence of anti-Leptospira spp. antibodies, according to the MAT in the municipalities of Nova Guarita and Nova Santa Helena, MT, Brazil, 2016.

\begin{tabular}{cccc}
\hline Municipality & Samples & Positive & Negative \\
\hline Nova Santa Helena & 448 & $104(23.2 \%)$ & $344(76.7 \%)$ \\
Nova Guarita & 519 & $70(13.4 \%)$ & $449(86.5 \%)$ \\
Total & 967 & $174(17.9 \%)$ & $793(82.1 \%)$ \\
\hline
\end{tabular}

Considering the frequency of reactive animals on farms, a prevalence of $95.6 \%(95 \% \mathrm{CI}=90.8-100 \%)$ was observed analyzed holdings was $83.6 \%(95 \% \mathrm{CI}=79.4-87.8 \%)$ (Table 2).in Nova Santa Helena and $73.0 \%$ $(95 \% \mathrm{CI}=69.4-76.7 \%)$ in Nova Guarita. Total prevalence among the 49

Table 2. Prevalence of properties considered focus of anti-Leptospira spp. antibodies according to the MAT in the municipalities of Nova Guarita and Nova Santa Helena, MT, Brazil, 2016.

\begin{tabular}{cccc}
\hline Municipality & Properties & Positive & Negative \\
\hline Nova Santa Helena & 23 & $22(95.6 \%)$ & $1(4.3 \%)$ \\
Nova Guarita & 26 & $19(73.0 \%)$ & $7(26.9 \%)$ \\
Total & 49 & $41(83.6 \%)$ & $8(16.3 \%)$ \\
\hline
\end{tabular}

Considering the frequency of the 20 serovarieties tested in the MAT, Wolffi was the most frequent of the 174 positive samples, with 83 reactive animals (47.7\%), followed by serovarieties Hardjo (16.1\%), Hardjo - Bolivia sample (11.0\%), Australis (7.4\%), Grippotyphosa (4.6\%), Pomona (3.4\%), Batavie (3.4\%),
Autumnalis (1.7\%), Icterohaemorrhagiae (1.7\%), Hebdomadis (1.1\%), Hardjo-bovis $(1.1 \%)$, and Castellonis $(0.5 \%)$. There were no titers for serovarieties Calledoni, Javanica, Hardjo - Lagoa sample, Hardjo - Norma sample, Panama, Serjroe, Shermani, or Szwajizak. 
Serovariety Wolffi also showed the highest titrations for anti-Leptospira spp. antibodies, followed by serovarieties Hardjo, Hardjo - Bolivia sample, Australis, Grippotyphosa, Autumnalis,
Batavie, Castellonis, Hardjo-bovis, Hebdomadis, Icterohaemorrhagiae, and Pomona, with titers ranging from 1:100 to 1:800 (Table 3).

Table 3. Titration of anti-Leptospira spp. antibodies for the different serovarieties tested in the municipalities of Nova Guarita and Nova Santa Helena, MT, Brazil, 2016.

\begin{tabular}{cccccc}
\hline \multirow{2}{*}{ Serovariety } & $\mathbf{N}(+)$ & \multicolumn{4}{c}{ Titers } \\
\cline { 3 - 6 } & & $\mathbf{1 0 0}(\boldsymbol{\%})$ & $\mathbf{2 0 0}(\boldsymbol{\%})$ & $\mathbf{4 0 0}(\boldsymbol{\%})$ & $\mathbf{8 0 0}(\mathbf{\%})$ \\
\hline Wolffi & 83 & $49(59.0)$ & $24(28.9)$ & $6(7.2)$ & $4(4.8)$ \\
Hardjo & 28 & $18(64.2)$ & $8(28.5)$ & $2(7.1)$ & $-(0.0)$ \\
Hardjo - Bolivia & 19 & $5(26.3)$ & $4(21.0)$ & $10(52.6)$ & $-(0.0)$ \\
Australis & 13 & $9(69.2)$ & $2(15.3)$ & $2(15.3)$ & $-(0.0)$ \\
Grippotyphosa & 8 & $5(62.5)$ & $2(25.0)$ & $1(12.5)$ & $-(0.0)$ \\
Bataviae & 6 & $5(83.3)$ & $1(16.6)$ & $-(0.0)$ & $-(0.0)$ \\
Pomona & 6 & $5(83.3)$ & $1(16.6)$ & $-(0.0)$ & $-(0.0)$ \\
Autumnalis & 3 & $2(66.6)$ & $1(33.3)$ & $-(0.0)$ & $-(0.0)$ \\
Icterohaemorrhagiae & 3 & $2(66.6)$ & $1(33.3)$ & $-(0.0)$ & $-(0.0)$ \\
Hardjobovis & 2 & $1(50)$ & $1(50)$ & $-(0)$ & $-(0)$ \\
Hebdomadis & 2 & $1(50)$ & $1(50)$ & $-(0)$ & $-(0)$ \\
Castelonis & 1 & $1(100)$ & $-(0)$ & $-(0)$ & $-(0)$ \\
\hline
\end{tabular}

\section{Discussion}

The prevalence of animals with antiLeptospira spp. antibodies was $17.9 \%$ (174/967), $7.4 \%$ (13/174) of them being positive for two or more serovarieties, and $83.6 \%$ (41/49) of properties with at least one reactive animal. In other studies conducted in Mato Grosso State, researchers reported higher prevalences than those observed. Madruga et al. (1980) carried out the first epidemiological survey of bovine leptospirosis in the state of Mato Grosso and obtained an animal prevalence of $74.3 \%$. In another study in Mato Grosso as well, Favero et al. (2001) reported an animal prevalence of $62.4 \%$ (148/237), serovarieties Hardjo $(82.4 \% ; 122 / 148)$ and Wolffi $(6.0 \% \mid 9 / 148)$ being the most frequent among the 23 included in the MAT. Sarmento et al. (2012) observed a prevalence of $62.6 \%(743 / 1186)$ with 23 serovarieties. After inclusion of others serotypes, these authors found an animal prevalence of $75.4 \%$ (895/1186). This significant difference suggests that the use of a larger number of serovarieties allows for an increase in the sensitivity of the MAT. These findings indicate the need to carry out diagnosis of herds in Mato Grosso as routine, besides the implementation of control measures and prophylaxis, as systematic vaccination.

In other studies conducted in Brazil, results for prevalence ranged from 13.3 to $18 \%$. Rolim et al. (2013) detected a prevalence of $13.3 \%$ (55/412) among uncastrated male cattle slaughtered in
Pernambuco State, using 27 serovarieties in the MAT. Mineiro et al. (2011) found an animal prevalence of $38.3 \%$ (23/60) in cows from Piauí State, Northeastern Brazil, using 11 serovarieties, the most frequent being Hardjo, with $86.9 \%$ $(20 / 23)$ of the animals positive.

Herrmann et al. (2012) identified 39.0\% (531/1360) reactive animals by MAT test with 17 serovarieties in Southern Brazil. Castro et al. (2008) reported a prevalence of 49.0\% (4026/8216) in the state of São Paulo. Nicolino et al. (2014) observed a prevalence of $20.6 \%(603 / 2915)$ in Minas Gerais State. According to the authors, serovariety Hardjo - Bolivia sample showed a frequency of $18.7 \%$ (113/603). Nicolino et al. (2014) used the same 20 serovarieties tested in the present study, and in both cases, only cows aged 24 months or older were included.

The differences between results may be attributed to factors such as the serovarieties used in the MAT; differences between populations; rearing systems, animal handling; and environmental conditions (Favero et al., 2001; Araújo et al., 2005; Nicolino et al., 2014). According to Figueiredo et al. (2009), beef farms and the Zebu breed were associated to the higher risk of herd infection by leptospiras, similarly to the population focused in this study.

In terms of frequency, serovarieties Wolffi, Hardjo, and Hardjo - Bolivia sample were the most frequent, with $47.7 \%$ (83/174), $16.0 \%$ (28/174), and $10.9 \%$ (19/174), respectively. Campos Junior 
et al. (2006) reported a prevalence of $74.2 \%$ (104/140) of animals reactive in the MAT, with serovarieties Wolffi $(19.2 \%$ | 20/104) and Hardjo $(15.3 \%$ | 16/104) being the most frequent, reinforcing the possibility of cross-infection between the two serovarieties. Many authors have reported higher frequencies of serovariety Hardjo in Brazilian cattle and elevated occurrence of cross-reactions between both species in MAT (Hashimoto et al., 2012; Herrmann et al., 2012; Sarmento et al., 2012; Pimenta et al., 2014).

Although the hypothesis of infection by serovariety Wolffi it not discarded, there might have been paradoxical reactions between serovarieties Wolffi and Hardjo, when, occasionally, higher titers are obtained with a serovariety different from that which is in fact infecting the animal. This factor is a result of the antigenic similarity among the serovarieties of the Sejroe group (Faine et al., 1999; Lilenbaum and Souza, 2003).

\section{Conclusion}

The prevalence of Leptospira spp. in cows in the municipalities of Nova Santa Helena and Nova Guarita is $17.9 \%$. The most frequent serovarieties are Wolffi, Hardjo, and Hardjo - Bolivia sample. The study revealed presence of different serovarieties and a high prevalence $(83.6 \%)$ of positive herds. No titers were observed for serovarieties Calledoni, Javanica, Hardjo - Lagoa sample, Hardjo - Norma sample, Panama, Serjroe, Shermani, or Szwajizak.

\section{Conflict of Interest}

The authors declare that they have no competing interests.

\section{Ethics Committee}

The authors whose names are listed above certify that they have not committed a willful act of abuse, cruelty, or neglect animal rights included on this study. The Ethics Committee for Animal Use of Embrapa Agrosilvopastoral, Sinop/Mato Grosso State, Brazil, has approved the study under number 00118 .

\section{Acknowledgements}

Special thanks to the "Instituto Desidério Finamor".

\section{References}

AUSVET ANIMAL HEALTH SERVICES. EpiTools epidemiological calculators. 2016. Disponível em: $<$ http://epitools.ausvet.com.au/content.php?pag e=home $>$. Acesso em: 09 dec. 2016.

Araújo, V.E.M.; Moreira, E.C.; Naveda, L.A.B. Frequency of anti-Leptospira interrogans agglutinins in bovine serum samples in Minas Gerais, Brazil 1980 to 2002. Arquivo Brasileiro de Medicina Veterinária e Zootecnia, 57: 430-435, 2005.

Campos Júnior, A.C.P.; Freneau, G.E.; Juliano, R.S.; Acypreste, C.S.; Dias Filho, F.C.; Martins, M.E. Prevalência de anticorpos anti-Leptospira em machos bovinos na microrregião de Goiânia. Ciência Animal Brasileira, 7: 439446, 2006.

Castro, V.; Azevedo, S.S.; Gotti, T.B.; Batista, C.S.A.; Gentili, J.; Moraes, Z.M.; Souza, G.O.; Vasconcellos, S.A.; Genovez, S.E. Soroprevalência da leptospirose em fêmeas bovinas em idade reprodutiva no Estado de São Paulo, Brasil. Arquivos do Instituto Biológico, 75: 3-11, 2008.

Cole, J.R.; Sulzer, C.R.; Pursell, A.R. Improved microtechnique for the leptospiral microscopic agglutination test. Applied Microbiology, 25: 976-980, 1973.

Dean, A.G.; Ddean, J.A.; Colombier, D.; et al. EpiInfo, Version 6: A word processing database and statistics program for epidemiology on microcomputers. Atlanta: CDC, 1994. 601p.

Dohoo, I.; Martin, W.; Stryhn, H., Sampling. In: I. Dohoo, W. Martin, H. Stryhn, Veterinary epidemiologic research. Charlottetown: Atlantic Veterinary College, 2003. p.27-47.

Ellis W.A. Animal leptospirosis. In: Adler, B. (ed.). Current topics in microbiology and immunology. Berlin Heidelberg: Springer, 2015. p. 99-137.

Faine, S.; Adler, Bolin, C.; Perolat, P. Leptospiras and leptospirosis. $2^{\text {nd }}$ ed. Australia: Medicine Science, 1999. 272p.

Favero, M.; Pinheiro, S.R.; Vasconcellos, S.A.; Morais, Z.M., Ferreira, F., Ferreira Neto, J.S. Leptospirose bovina: variantes sorológicas predominantes em colheitas efetuadas no período de 1984 a 1997 em rebanhos de 21 estados do Brasil. Arquivos Instituto Biológico, 68: 29-35, 2001. 
Figueiredo, A.O.; Pellegrin, A.O.; Gonçalves, V.S.P.; Freitas, E.B.; Monteiro, L.A.R.C.; Oliveira, J.M.; Osório, A.L.A.R. Prevalência e fatores de risco para a leptospirose em bovinos de Mato Grosso do Sul. Pesquisa Veterinária Brasileira, 29: 375-381, 2009.

Figueiredo, Í.L.; Higino, S.S.S.; Alves, C.J.; Fava, C.D.; Carretero, M.E.; Azevedo, S.S. Interrelação entre frequência de anticorpos antiLeptospira spp. e exames histopatológicos (hematoxilina-eosina e Warthin-Starry) em suínos abatidos no Semiárido Paraibano. Arquivos do Instituto Biológico, 80: 27-34, 2013.

Galton, M.M.; Sulzer, C.R.; Santa Rosa, C.A.; Fields, M.J. Application of a micro technique to the agglutination test for leptospiral antibodies. Applied Microbiology, 13: 81-85, 1965.

Girio, T.M.S.; Magajevski， F.S.; Girio, R.J.S.; Miashyro, S.; Rodrigues, L.; Scarcelli, E.; Toma, S. Uso de estreptomicina na eliminação da leptospiúria em touros. Arquivos do Instituto Biológico, 72: 161-170, 2005.

Hashimoto, V.Y.; Dias, J.A.; Spohr, K.A.H.; Silva, M.C.P.; Andrade, M.G.B.; Muller, E.E.; Freitas, J.C. Prevalência e fatores de risco associados à Leptospira spp. em rebanhos bovinos da região centro-sul do estado do Paraná. Pesquisa Veterinária Brasileira, 32: 99-105, 2012.

Herrmann, G.P.; Lage, A.P.; Moreira, E.C. Soroprevalência de aglutininas anti-Leptospira spp. em ovinos nas Mesorregiões Sudeste e Sudoeste do Estado Rio Grande do Sul, Brasil. Ciência Rural, 34: 443-448, 2004.

Herrmann, G.O.; Rodrigues, R.O.; Cader, R. Soroprevalência de leptospirose em bovinos nas mesorregiões sudeste e sudoeste do estado Rio Grande do Sul, Brasil. Ciência Animal Brasileira, 13: 131-138, 2012.

IBGE, Instituto Brasileiro de Geografia e Estatística. Divisão territorial do Brasil e limites territoriais, 2015. Disponível em: <http://www.cidades.ibge.gov.br/xtras/temas>. Acesso em: 20 jun. 2016.

IBGE, Instituto Brasileiro de Geografia e Estatística. Indicadores - pesquisa pecuária municipal, 2016. Disponível em: http://www.brasil.gov.br/economia-e-emprego >. Acesso em: 15 jun. 2016.

INDEA, Instituto de Defesa Agropecuária do Estado de Mato Grosso - Pesquisa pecuária, 2015. Disponível
$<$ http://www.indea.mt.gov.br/defesa-sanitariaanimal/downloads/relatorio-de-populacao-bovina-existente-novembro2015/161776>.

Acesso em: 30 out. 2016.

Johnson, R.; Harris, V.G. Differentiation of pathogenic of leptospires. Journal of Bacteriology, 94: 27-31. 1967

Kremer, F.S.; Eslabão, M.R.; Provisor, M.; Woloski, R.D.S.; Ramires, O.V.; Moreno, L.Z.; Moreno, A.M.; Hamond, C.; Lilenbaum, W.; Dellagostin, O.A. Draft genome sequences of Leptospira santarosai strains U160, U164, and U233, isolated from asymptomatic cattle. Genome Announcements, 3: 910-915, 2015.

Madruga, C.R; Aycardi, E.; Putt, N. Frequência de aglutininas anti-leptospira em bovinos de corte da região sul de Cerrado do Estado de Mato Grosso. Arquivos da Escola de Veterinária da Universidade Federal de Minas Gerais, 32: 245-249, 1980.

Mineiro, A.L.B.B.; Vieira, R.J.; Costa, E.A. Serology, polymerase chain reaction and histopathology for leptospirosis in samples collected at slaughter from dairy cows of Parnaiba region, state of Piauí, Brazil. Pesquisa Veterinária Brasileira, 31: 859-866, 2011.

Miraglia, F. Molecular and serological characterization of Leptospira interrogans serovar Canicola isolated from dogs, swine, and bovine in Brazil. Tropical Animal Health and Production, 45: 117-121, 2013.

Nicolino, R.R.; Lopes, L.B.; Rodrigues, R.O.; Teixeira, J.F.B.; Haddad, J.P.A. Prevalence and spatial analysis of antileptospiral agglutinins in dairy cattle - Microregion of Sete Lagoas, Minas Gerais, 2009/2010. Arquivo Brasileiro de Medicina Veterinária e Zootecnia, 66: 648-654, 2014.

Pimenta, C.L.R.M.; Castro, V.; Clementino, I.J. Leptospirose bovina no Estado da Paraíba: prevalência e fatores de risco associados à ocorrência de propriedades positivas. Pesquisa Veterinária Brasileira, 34: 332-336, 2014.

Rolim, M.B.Q.; Barros, S.E.M.; Silva, V.C.L.; Santana, V.L.A.; Souza, M.A.; Harop, M.H.V.; Mota, R.A.; Oliveira, M.A.L.; Moura, A.P.B.L.; Lima, P.F. Determinação de anticorpos antiLeptospira spp. e anti-Brucella abortus em bovinos abatidos em matadouro público no estado de Pernambuco. Revista de Medicina Veterinária, 7: 24-30, 2013.

Sarmento, A.M.C. Emprego de estirpes Leptospira spp. isoladas no Brasil na micro técnica de 
Soroaglutinação microscópica aplicada ao diagnóstico da leptospirose em rebanhos bovinos de oito estados brasileiros. Pesquisa Veterinária Brasileira, 32: 601-606, 2012.

Souza, A.P.; Mota, L.L.; Zamadei, T. Classificação climática e balanço hídrico climatológico no estado de Mato Grosso. Nativa, 1: 34-43, 2013.
Viana, K.F.; Zanini, M.S.; Moreira, E.C. Frequência de anticorpos anti-Leptospira spp. em rebanhos bovinos da bacia leiteira do Caparaó, Estado do Espírito Santo. Archives of Veterinary Science, 2: 100-106, 2010. 